\title{
Efektivitas Pemanfaatan Aplikasi Instagram Dalam Edukasi Pencegahan Penularan Covid-19 Dikalangan Mahasiswa
}

\author{
Giofanny Theresia ${ }^{1}$, Anwar Maulana ${ }^{2}$, Finna Puspita ${ }^{3}$, Femmy Effendy $^{4^{*}}$ \\ 1,2,3,4*Sistem Informasi, STMIK Rosma, Karawang \\ Email: femmy@rosma.ac.id
}

\begin{abstract}
Social media is an application to communicate with other people who use the internet. However, in this COVID19 pandemic, social media can be used not only to communicate with other people but also as an information center regarding vaccines, information on oxygen availability, information on the number of COVID-19 patients, information on the current situation and conditions, prevention education and protection from COVID19, moral support from virtual communities, and means for entertainment. In social media, the information are well presented in a unique and interesting way, so the people will understand easily. This study aims to discover the effectiveness and influence of the instagram application for educating the prevention of COVID-19 transmission among the college students. The research method in this scientific work is descriptive research, while the method is a survey that take a sample from population and used questionnaire as the main tool of data. The sample was taken by 51 respondents used the Non Probability Sampling technique with the Saturated Sampling (census) method, when all respondents in the population were sampled. The analysis result is a descriptive statistic where's the answer from indicator research about influence of the instagram application for educating the prevention of COVID-19 transmission among college students will be able to reach the effectiveness. In accordance with the result of questionnaire, most of the respondents gave a positive response and agreed that the instagram application was effective to educating the college students about the prevention of COVID-19 transmission.
\end{abstract}

Keyword : Social Media, Instagram, Education, COVID-19, Descriptive

\begin{abstract}
Abstrak
Media sosial adalah suatu aplikasi untuk berkomunikasi dengan orang lain yang memanfaatkan internet. Namun pada kondisi pandemi COVID-19 ini media sosial dapat dimanfaatkan tidak hanya untuk berkomunikasi dengan orang lain saja tetapi juga sebagai pusat informasi mengenai vaksin, informasi mengenai ketersediaan oksigen, informasi mengenai jumlah pasien COVID-19, informasi situasi dan kondisi terkini,edukasi pencegahan dan perlindungan dari COVID-19, dukungan moral dari komunitas virtual, dan sarana hiburan. Dalam media sosial berbagai informasi tersebut disajikan dengan cara yang unik dan menarik sehingga masyarakat tertarik dan mudah mengerti. Penelitian ini bertujuan untuk mengetahui seberapa besar efektifitas dan pengaruh dari pemanfaatan aplikasi Instagram dalam mengedukasi pencegahan penularan COVID-19 di kalangan mahasiswa. Metode penelitian yang digunakan pada karya tulis ilmiah ini adalah penelitian descriptive. Sedangkan metode yang di lakukan adalah metode survey dimana penelitian mengambil sampel dari populasi dan menggunakan kuisoner sebagai alat pengumpulan data yang pokok. Sampel yang di ambil sebanyak 51 Responden dengan menggunakan teknik teknik Non Probability Sampling dengan metode Sampling Jenuh (sensus), yaitu pengambilan sampel bila semua responden dalam populasi dijadikan sampel. Hasil Analisis dimana hasil analisis descriptive statistic jawaban indicator penelitian mengenai pemanfaatan aplikasi Instagram dalam edukasi pencegahan penularan COVID-19 di kalangan mahasiswa dapat mencapai tujuannya secara efektif, sesuai dengan hasil kuisoner yang didapat sebagian besar responden memberikan respon postif dan setuju bahwa aplikasi instagram efektif dalam mengedukasi mahasiswa mengenai pencegahan penularan COVID-19.
\end{abstract}

Kata Kunci : Sosial Media, Instagram, Edukasi, COVID-19, Deskriptif

\author{
Article History : \\ Received 10, September, 2021 \\ Revised 22, Oktober, 2021 \\ Accepted 16, November, 2021 \\ Corresponding Author: \\ Nama Penulis: Femmy Effendy
}

Jurnal Interkom: Jurnal Publikasi Ilmiah Bidang Teknologi Informasi dan Komunikasi

Volume 16 Nomor 03 Bulan Oktober - Tahun 2021 
Departemen: Sistem Informasi

Instansi: STMIK Rosma

Alamat: Jln. Kertabumi No. 62 Karawang Barat

Email Penulis: femmy@ rosma.ac.id

\section{Pendahuluan}

COVID-19 mewabah sejak akhir tahun 2019 di Wuhan, China dan menyebar secara cepat ke seluruh dunia pada awal tahun 2020 [1] termasuk di Indonesia. Dimulai dengan kasus COVID-19 pertama pada bulan Maret yang dikonfirmasi oleh Presiden Joko Widodo yang menyatakan bahwa terdapat 2 warga negara Indonesia terjangkit COVID-19 yakni perempuan berusia 31 tahun dan ibu berusia 64 tahun. COVID-19 termasuk penyakit menular yang pengendaliannya adalah dengan meminimalisir kontak antara orang yang terjangkit COVID-19.

Oleh karena itu munculah kebijakan diberbagai tingkat berskala daerah hingga nasional untuk mengurangi jumlah pasien positif dan penularan COVID-19 mulai dari adanya kebijakan Pembatasan Sosial Berskala Besar (PSBB) pada Mei 2020, kenormalan baru (new normal) pada Juni 2020 yang merupakan rekomendasi World Health Organization untuk seluruh dunia, Pemberlakuan Pembatasan Kegiatan Masyarakat (PPKM) dengan skala mikro pada Februari 2021, hingga yang terbaru adalah kebijakan Pemberlakuan Pembatasan Kegiatan Masyarakat (PPKM) dengan status Darurat untuk wilayah Jawa - Bali pada Juli 2021.

Kini ada Berbagai akun Instagram yang menyajikan edukasi mengenai COVID-19 pun telah tersedia dengan harapan dapat meningkatkan kesadaran masyarakat Indonesia mengenai COVID19 dan memberikan informasi yang akurat dan terpercaya dengan konten yang menarik dan mudah dimengerti. Pada penelitian sebelumnya menemukan iklan dengan gambar rokok elektronik (vape) dapat lebih mempengaruhi asumsi masyarakat sehingga menganggap bahwa rokok tradisional lebih berbahaya dan menormalkan rokok elektronik (vape) [2] . Dari penelitian tersebut dapat ditarik kesimpulan bahwa Instagram termasuk efektif dalam membagikan informasi Kesehatan apabila dengan cara yang menarik sehingga masyarakat mudah mengerti edukasi yang dimaksud,selain itu kegiatan edukasi pun lebih murah dan mudah karena dapat dilakukan dimana saja dan kapan saja.

Berdasarkan latar belakang tersebut peneliti tertarik untuk menganalisis apakah pemanfaatan aplikasi instagram efektif dalam memberikan edukasi pencegahan penularan COVID-19 dikalangan mahasiswa dan apakah dengan pemanfaatan aplikasi instagram dapat meningkatkan kesadaran mahasiswa mengenai pencegahan penularan COVID19. Adapun analisis data dilakukan secara descriptive, dengan perhitungan descriptive statistic menggunakan tools software SPSS 21.

Hasil dari penelitian ini adalah aplikasi Instagram diharapkan dapat efektif dalam mengedukasi dan meningkatkan kesadaran mahasiswa akan pencegahan penularan COVID-19.

\section{Tinjauan Pustaka}

\subsection{COVID-19}

COVID-19 (Corona Virus Diseaseas 2019) adalah penyakit yang disebabkan oleh SARS-CoV-2 [3], ini merupakan virus baru yang berasal dari jenis keluarga Coronavirus. Virus ini menyebabkan gangguan sistem pernafaasan dan bergejala seperti flu biasa yaitu demam,kehilangan 
penciuman, dan sesak nafas pada beberapa kasus,itulah yang menyebabkan seseorang tidak menyadari dirinya terjangkit COVID19 dan dapat menimbulkan kekhawatiran berlebih pada flu biasa [4]. COVID-19 menular melalui air liur pasien yang dikeluarkan saat batuk/bersin, tangan yang menyentuh benda terkontaminasi virus,kontak langsung dengan pasien COVID-19, dan cairan mata yang disebabkan sentuhan dari tangan yang terkontaminasi COVID-19 [5].

COVID-19 mewabah sejak akhir tahun 2019 di Wuhan,China dan menyebar secara cepat ke seluruh dunia pada awal tahun 2020 [1] termasuk di Indonesia. Dimulai dengan kasus COVID-19 pertama pada bulan Maret yang dikonfirmasi oleh Presiden Joko Widodo yang menyatakan bahwa terdapat 2 warga negara Indonesia terjangkit COVID-19 yakni perempuan berusia 31 tahun dan ibu berusia 64 tahun.

Berdasarkan data worldometers pada 29 Mei 2020,jumlah total kasus positif COVID-19 di dunia sebanyak 5.920.258 pasien, dengan angka kematian mencapai 362.368 jiwa dan angka kesembuhan 2.592.085 orang. Amerika Serikat menempati posisi pertama dengan pemilik kasus COVID-19 terbanyak pada Mei 2020,disusul oleh Brasil dan Rusia. Di Indonesia sendiri total pasien positif sebanyak 25.216 pasien dengan angka kematian sebanyak 1.520 jiwa dan kesembuhan sebanyak 6.492 orang. DKI Jakarta menempati posisi dengan provinsi kasus COVID-19 terbanyak hingga 29 Mei 2020 [6]. Karena skala penyebaran COVID-19 terjadi secara global di seluruh dunia maka World Health Organization menetapkan COVID-19 sebagai pandemi secara resmi pada 9 Maret 2020.

\subsection{Sosial Media}

Sosial media merupakan sebuah media daring yang digunakan satu sama lain, yang para penggunanya bisa dengan mudah berpartisipasi, berinteraksi, berbagi, dan menciptakan isi blog, jejaring sosial, forum dan dunia virtual tanpa dibatasi oleh ruang dan waktu. [7]

Andreas Kaplan dan Michael Haenlein [8] mendefinisikan sosial media sebagai "sebuah kelompok aplikasi berbasis internet yang dibangun di atas dasar ideologi dan teknologi Web 2.0 dan memungkinkan penciptaan dan pertukaran user-generated content".

\subsection{Aplikasi Instagram}

Instagram berasal dari pengertian keseluruhan fungsi aplikasi tersebut. Kata "insta" berasal dari kata "instan", seperti kamera polaroid yang ada pada masanya lebih dikenal dengan sebutan "foto instan". Sedangkan untuk kata "gram" berasal dari kata "telegram" yang cara kerjanya untuk mengirimkan informasi kepada orang lain dengan cepat.[9]

Instagram atau yang biasa disingkat IG merupakan sebuah aplikasi berbagi foto dan video yang memungkinkan pengguna mengambil foto, mengambil video, menerapkan filter digital, dan membagikannya ke berbagai layanan jejaring sosial. [9]

\subsection{Edukasi}

Edukasi menurut Kamus Besar Bahasa Indonesia (KBBI) adalah proses pengubahan sikap dan tata laku seseorang atau sekelompok orang dalam usaha mendewasakan manusia melalui upaya pengajaran dan pelatihan.

Menurut Driyarkara [10], edukasi adalah suatu usaha di dalam memberikan peganggan kepada manusia serta juga mengangkat yang muda supaya lebih insani. Terutama di dalam mensiasati perkembangan jaman yang berjalan dengan begitu cepat. Penting supaya manusia itu tetap bisa menyesuaikan sebagai peranannya. 


\section{Metode Penelitian}

Metode penelitian yang digunakan adalah penelitian descriptive, dimana penelitian di lakukan untuk menggambarkan serta menjelaskan pemanfaatan aplikasi Instagram dalam edukasi pencegahan penularan COVID-19 dikalangan mahasiswa efektif dan dapat meningkatkan tingkat kesadaran mahasiswa dalam melakukan pencegahan penularan COVID-19. Sedangkan metode yang di lakukan adalah metode survey dimana penelitian mengambil sampel dari populasi dan menggunakan kuisoner sebagai alat pengumpulan data.

\subsection{Sumber Data}

Populasi dalam penelitian ini adalah mahasiswa yang berada di Indonesia. Mahasiswa yang dituju peneliti untuk menjadi sampel penelitian adalah mahasiswa aktif dari berbagai kampus yang ada di Indonesia, dan merupakan pengguna aplikasi instagram.

Sampel adalah bagian dari populasi yang akan diteliti. Sugiyono [11], mengatakan bahwa: "Bila semua anggota populasi digunakan sebagai sampel maka disebut sampling jenuh atau istilah lainnya adalah sensus."

Dalam penelitian ini pengambilan sampel menggunakan teknik Non Probability Sampling dengan metode Sampling Jenuh (sensus), yaitu pengambilan sampel bila semua responden dalam populasi dijadikan sampel. Hal ini dilakukan karena jumlah responden dalam populasi kecil, kurang dari 100 orang.

\subsection{Teknik Pengambilan Sampel}

Pengambilan sampel yang di gunakan dalam penelitian ini adalah non prohability sampling yaitu metode Sampling Jenuh (sensus) [12] yaitu pengambilan sampel bila semua responden dalam populasi dijadikan sampel. Peneliti memilih sample secara subjectif yaitu pada mahasiswa perguruan tinggi yang memiliki akun aplikasi Instagram, pemilihan sampel dilakukan agar sampel dapat bersifat relevan dengan desain peneliti.

Penelitian yang dilakukan menggunakan kuisioner online yang disebarkan langsung kepada responden dengan alat bantu survey online yaitu Google Form. Google Form adalah layanan yang berguna untuk membantu anda merencanakan acara, mengirim survei, memberikan siswa atau orang lain kuis, atau mengumpulkan informasi yang mudah dengan cara yang efisien.

Kuesioner yang digunakan sebagai instrument penelitian ini guna menghasilkan data yang akurat dengan menggunakan skala Likert untuk mengukur pendapat dan persepsi seseorang akan suatu objek yang akan diteliti

Tabel 1. Skala Likert

\begin{tabular}{|c|c|}
\hline Pilihan Jawaban & Skor \\
\hline Sangat Tidak Setuju & 1 \\
\hline Tidak Setuju & 2 \\
\hline Netral & 3 \\
\hline Setuju & 4 \\
\hline Sangat Setuju & 5 \\
\hline
\end{tabular}

\subsection{Analisis Data}

Proses analisis data dilakukan setelah responden terkumpul. Analisis data dilakukan secara descriptive, yaitu dengan mengambarkan sebuah data dan menjelaskan data dengan perhitungan descriptive statistic menggunakan alat bantu software IBM Statistics SPSS 21. Tahap terakhir dari penelitian karya tulis ilmiah ini adalah menarik kesimpulan dari permasalahan yang telah ditentukan. Berikut kerangka tahapan prosedur yang dilakukan pada penelitian ini : 


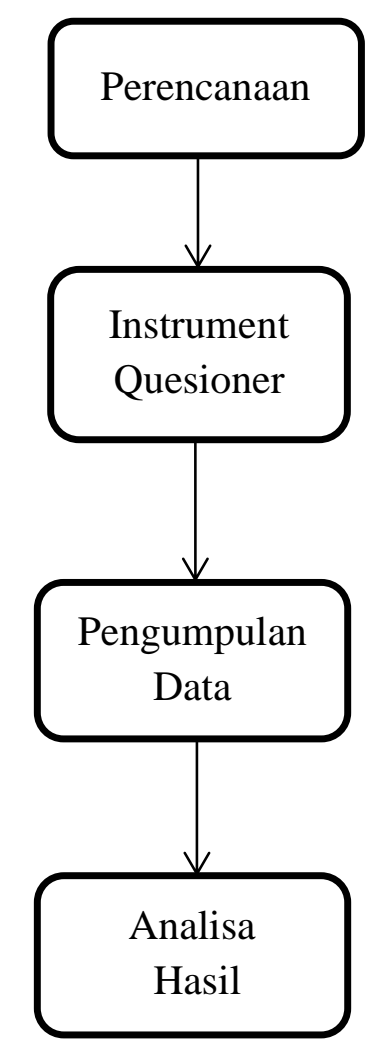

Gambar 1. Prosedur Penelitian

A. Perencanaan: pada tahap ini peneliti menyusun topik-topik yang ingin diteliti , yang didalamnya terdapat data dan informasi yang digali berdasarkan sumber data, teknik pengambilan data serta pertanyaan-pertanyaan yang ingin diajukan kepada sumber data.

B. Instrument Quesioner: pada tahap ini peneliti menyusun instrument penelitian yaitu berupa quesioner berdasarkan daftar pertanyaan yang telah disusun.

C. Pengumpulan Data: pada tahap ini peneliti melakukan pengumpulan data berdasarkan instrumen penelitian yang telah disusun.

D. Analisa Hasil: pada tahap ini peneliti melakukan analisa hasil berdasarkan data yang telah terkumpul.

\section{Hasil dan Pembahasan}

A. Karakteristik Responden Berdasarkan Jenis Kelamin

Karakteristik responden berdasarkan jenis kelamin dibagi menjadi dua kategori, yaitu laki-laki dan perempuan. Berikut merupakan data diperoleh mengenai karakteristik responden berdasarkan jenis kelamin.

Tabel 2. Karakteristik Responden Berdasarkan Jenis Kelamin

\begin{tabular}{|c|c|c|c|}
\hline No & Kategori & $\mathrm{f}$ & Presentase $(\%)$ \\
\hline 1 & Laki-Laki & 17 & $33 \%$ \\
\hline 2 & Perempuan & 34 & $67 \%$ \\
\hline & Total & 51 & $100 \%$ \\
\hline
\end{tabular}

Sumber: Data diolah, 2021

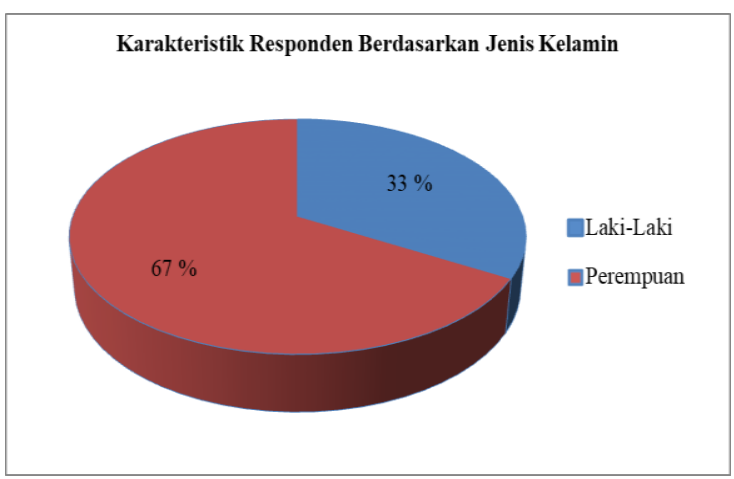

Gambar 2. Karakteristik Responden Berdasarkan Jenis Kelamin

Sumber: Data diolah, 2021

Berdasarkan perolehan data pada Tabel 2 dapat diketahui bahwa mayoritas responden yang didapat pada penelitian ini merupakan mahasiswa dengan jenis kelamin perempuan, yaitu sebanyak 34 orang $(67 \%)$ sedangkan mahasiswa dengan jenis kelamin laki-laki hanya sebanyak 17 orang $(33 \%)$. Hal ini menjelaskan bahwa dari 51 responden yang ditemui pada penelitian ini, mayoritas mahasiswa yang memanfaatkan aplikasi Instagram untuk mendapatkan informasi edukasi mengenai pencegahan penularan COVID-19 berjenis kelamin perempuan dengan hasil perolehan $67 \%$. Sedangkan mahasiswa berjenis kelamin laki-laki yang berhasil peneliti temui hanya $33 \%$ saja yang memanfaatkan 
aplikasi Instagram untuk mendapatkan informasi edukasi mengenai pencegahan penularan COVID-19.

B. Karakteristik Responden Berdasarkan Usia

Karakteristik responden berdasarkan usia dikategorikan menjadi dua kategori, yaitu rentang usia 18-22 tahun dan 2327tahun. Berikut data yang diperoleh mengenai karakteristik responden berdasarkan usia.

Tabel 3. Karakteristik Responden Berdasarkan

\begin{tabular}{|c|c|c|}
\hline \multicolumn{3}{|c|}{ Usia } \\
\hline Usia & $\mathrm{f}$ & Percent \\
\hline 18 - 22 Tahun & 43 & 84,3 \\
- 27 Tahun & 8 & 15,7 \\
Total & 51 & 100,0 \\
\hline
\end{tabular}

\begin{tabular}{|c|c|c|}
\hline Usia & $\begin{array}{c}\text { Valid } \\
\text { Percent }\end{array}$ & $\begin{array}{c}\text { Cumulative } \\
\text { Percent }\end{array}$ \\
\hline 18 - 22 Tahun & 84,3 & 84,3 \\
23 - 27 Tahun & 15,7 & 100,0 \\
Total & 100,0 & \\
\hline
\end{tabular}

Sumber: Data diolah, 2021

Berdasarkan Tabel 3 diatas dapat diketahui bahwa dari 51 responden yang didapat pada penelitian ini, didominasi oleh mahasiswa yang memiliki usia direntang 18-22 tahun, yaitu sebanyak 43 orang atau $84.3 \%$ responden yang usia nya 18-22 tahun yang merupakan usia umum rata-rata mahasiswa jenjang strata $1 \mathrm{di}$ Indonesia. Sedangkan $15.7 \%$ atau 8 orang lainnya merupakan mahasiswa yang berusia pada rentang 23-27 tahun.

\section{Descriptive Jawaban Responden}

Analisis descriptive ini bertujuan untuk memberikan suatu gambaran atau mendeskripsikan suatu data, yang dilihat berdasarkan nilai minimum, maxsimum, mean (rata-rata), deviasi standar dari masing-masing indikator penelitian. Analisis descriptive adalah statistik yang digunakan untuk menganalisa data dengan cara mendeskripsikan atau menggambarkan suatu data yang telah terkumpul sebagaimana adanya [11]. Berikut dibawah ini merupakan output analisis descriptive Statistic dari jawaban responden terhadap indikator penelitian mengenai pemanfaatan aplikasi instagram dalam edukasi pencegahan penularan COVID-19 dikalangan mahasiswa :

Tabel 4. Output Analisis Descriptive Statistic Jawaban Responden

\begin{tabular}{|c|c|c|c|c|c|c|c|c|c|c|c|c|}
\hline \multirow{3}{*}{ No. } & \multirow{3}{*}{ Indikator } & STS & TS & $\mathbf{N}$ & $\mathbf{S}$ & SS & \multirow{3}{*}{ Mean } & \multirow{3}{*}{ Modus } & \multirow{3}{*}{ Min } & \multirow{3}{*}{ Max } & \multirow{3}{*}{$\begin{array}{l}\text { Standar } \\
\text { Deviasi }\end{array}$} & \multirow{3}{*}{ Ket } \\
\hline & & f & f & f & f & f & & & & & & \\
\hline & & $\%$ & $\%$ & $\%$ & $\%$ & $\%$ & & & & & & \\
\hline \multirow{2}{*}{1} & \multirow{2}{*}{$\begin{array}{l}\text { Menghabiskan waktu } \\
\text { membuka instagram }\end{array}$} & 2 & 5 & 19 & 16 & 9 & \multirow{2}{*}{3,49} & \multirow{2}{*}{3} & \multirow{2}{*}{1} & \multirow{2}{*}{5} & \multirow{2}{*}{1,027} & \multirow{2}{*}{ Netral } \\
\hline & & $3,9 \%$ & $9,8 \%$ & $37,3 \%$ & $31,4 \%$ & $17,6 \%$ & & & & & & \\
\hline \multirow{2}{*}{2} & \multirow{2}{*}{$\begin{array}{l}\text { Sering melihat konten } \\
\text { mengenai COVID-19 }\end{array}$} & 2 & 2 & 12 & 19 & 16 & \multirow{2}{*}{3,88} & \multirow{2}{*}{4} & \multirow{2}{*}{1} & \multirow{2}{*}{5} & \multirow{2}{*}{1,032} & \multirow{2}{*}{ Setuju } \\
\hline & & $3,9 \%$ & $3,9 \%$ & $23,5 \%$ & $37,3 \%$ & $31,4 \%$ & & & & & & \\
\hline \multirow{2}{*}{3} & \multirow{2}{*}{\begin{tabular}{|l|} 
Tertarik dengan konten \\
COVID-19 \\
\end{tabular}} & 3 & 3 & 18 & 21 & 6 & \multirow{2}{*}{3,47} & \multirow{2}{*}{4} & \multirow{2}{*}{1} & \multirow{2}{*}{5} & \multirow{2}{*}{0,987} & \multirow{2}{*}{ Setuju } \\
\hline & & $5,9 \%$ & $5,9 \%$ & $35,3 \%$ & $41,2 \%$ & $11,8 \%$ & & & & & & \\
\hline \multirow{2}{*}{4} & \multirow{2}{*}{$\begin{array}{l}\text { Mengerti apa yang } \\
\text { disampaikan }\end{array}$} & 0 & 4 & 6 & 26 & 15 & 4,02 & 4 & 2 & 5 & 0,860 & Setuju \\
\hline & & $0 \%$ & $7,8 \%$ & $11,8 \%$ & $51 \%$ & $29,4 \%$ & 4,02 & 4 & 2 & & & \\
\hline 5 & Instagram efektif & 0 & 0 & 20 & 22 & 9 & 378 & 4 & 3 & 5 & 0730 & Setui \\
\hline J & memberikan edukasi & $0 \%$ & $0 \%$ & $39,2 \%$ & $43,1 \%$ & $17,6 \%$ & 3,10 & 4 & 3 & J & $0, / 30$ & stiugu \\
\hline 6 & Berniat melakukan & 3 & 1 & 4 & 30 & 13 & 3.96 & 4 & 1 & 5 & 0.979 & Setuiu \\
\hline 0 & pencegahan penularan & $5,9 \%$ & $2 \%$ & $7,8 \%$ & $58,8 \%$ & $25,5 \%$ & (, & 4 & 1 & & (3) & stiugu \\
\hline 7 & Kenyamanan & 2 & 1 & 19 & 18 & 11 & 369 & 3 & 1 & 5 & 0969 & Netral \\
\hline 1 & menggunakan instagram & $3,9 \%$ & $2 \%$ & $37,3 \%$ & $35,3 \%$ & $21,6 \%$ & , & J & 1 & J & , & tiverat \\
\hline
\end{tabular}

Sumber: Data diolah, 2021

Jurnal Interkom: Jurnal Publikasi Ilmiah Bidang Teknologi Informasi dan Komunikasi

Volume 16 Nomor 03 Bulan Oktober - Tahun 2021 
Dilihat dari data dalam Tabel 4 diatas yaitu output analisis descriptive statistic jawaban responden terhadap indikator penelitian mengenai pemanfaatan aplikasi instagram dalam edukasi pencegahan penularan COVID-19 dikalangan mahasiswa, dapat dijelaskan hasilnya sebagai berikut:

1. Pada indikator mengenai apakah responden sering menghabiskan waktunya untuk membuka instagram, responden memberikan respon baik, dengan mean 3,49. Dimana mayoritas pilihan jawaban responden memilih jawaban "Netral" yaitu sebanyak 19 orang $(37,3 \%)$, dan responden lainnya memilih jawaban "Setuju" sebanyak 16 orang $(31,4 \%)$, "Sangat Setuju" sebanyak 9 orang (17,6\%), "Tidak Setuju" sebanyak 5 orang $(9,8 \%)$, "Sangat Tidak Setuju" sebanyak 2 orang $(3,9 \%)$. Terlihat dari sebaran pilihan jawaban responden paling banyak bersikap netral, namun banyak juga responden yang setuju bahwa mereka sering menghabiskan waktunya untuk membuka instagram yaitu sebesar 31,4\% responden memilih jawaban "Setuju", dan 17,6\% responden memilih jawaban "Sangat Setuju", yang artinya aplikasi instagram masih menjadi pilihan responden untuk menghabiskan waktu mereka dengan melihat-lihat instagram.

2. Pada indikator mengenai apakah responden sering melihat konten atau postingan mengenai COVID-19 di instagram, responden memberikan respon sangat baik, dengan mean 3,88 . Dimana mayoritas pilihan jawaban responden memilih jawaban "Setuju" yaitu sebanyak 19 orang $(37,3 \%)$ dan responden lainnya yang memilih jawaban "Sangat Setuju" sebanyak 16 orang $(31,4 \%)$, yang artinya mayoritas responden sudah sering melihat konten atau postingan di instagram mengenai COVID-19, yang dimana melalui postingan tersebut mereka bisa mendapatkan info-info mengenai COVID-
19 dan edukasi pencegahan penularan COVID-19 melalui account-account official pemerintah seperti kemenkes_ri, satuantugascovid19,dan lainnya, atau melalui para influencer yang juga ikut serta memberikan edukasi pencegahan penularan COVID-19 melalui kontenkonten nya di instagram. Dan dilihat dari sebaran jawaban responden hanya sedikit yang jarang atau belum melihat konten postingan mengenai COVID-19, yaitu hanya sebanyak 12 orang $(23,5 \%)$ yang memilih jawaban "Netral", 2 orang $(3,9 \%)$ memilih jawaban "Tidak Setuju", dan 2 orang $(3,9 \%)$ memilih jawaban "Sangat Tidak Setuju", yang artinya aplikasi instagram dapat dijadikan media edukasi pencegahan penularan COVID-19, dan orang-orang bisa dengan mudah mendapatkan informasi mengenai COVID19 melalui konten edukasi yang disajikan di instagram yang pasti nya memalui account-account terpercaya dan akurat.

3. Pada indikator mengenai seberapa tertarik nya responden terhadap konten atau postingan tentang pencegahan penularan COVID-19 di instagram, responden memberikan respon sangat baik, yaitu dengan mean 3,47. Dimana mayoritas responden memilih jawaban "Setuju" dengan jumlah banyak responden yang menjawab sebanyak 21 orang $(41,2 \%)$ dan responden yang memilih jawaban "Sangat Setuju" sebanyak 6 orang $(11,8 \%)$, yang artinya mayoritas responden tertarik akan konten postingan yang disajikan di instagram mengenai pencegahan penularan COVID-19, kebanyakn dari mereka tertarik untuk membacanya, sehingga sudah tepat sasaran untuk memanfaatkan aplikasi instagram dalam memberikan edukasi pencegahan penularan COVID-19, karena terbukti mayoritas responden tertarik akan konten pencegahan penuluran COVID-19 yang disajikan dengan menarik melalui aplikasi instagram, tidak hanya 
berupa tulisan, edukasi pencegahan penularan COVID-19 di instagram dapat disajikan dalam bentuk video, gambar, story animasi, dan lain-lain. Dilihat dari sebaran pilihan jawaban responden, ada sebagian responden yang bersikap netral dengan memilih jawaban "Netral" yaitu sebanyak 18 orang $(35,3 \%)$. Responden yang memilih jawaban "Tidak Setuju" sebanyak 3 orang $(5,9 \%)$, dan responden yang memilih jawaban "Sangat Tidak Setuju" sebanyak 3 orang $(5,9 \%)$, yang artinya hanya sedikit dari jumlah responden yang tidak tertarik akan konten postingan pencegahan penularan COVID19 yang disajikan di aplikasi instagram, dan lebih tertarik membaca postingan mengenai pencegahan penularan COVID19 melalui media lain.

4. Pada indkator mengenai apakah responden mengerti apa yang disampaikan tentang pencegahan penularan COVID-19 di instagram, responden memberikan respon sangat baik, dengan mean 4,02. Dimana $51 \%$ responden memilih pilihan jawaban "Setuju" yaitu sebanyak 26 orang, dan $29,4 \%$ responden memilih pilihan jawaban "Sangat Setuju" yaitu sebanyak 15 orang. Artinya sebagian besar bahkan hampir seluruh responden mengerti akan informasi mengenai pencegahan penularan COVID-19 yang ditemui nya di instagram, mereka paham akan informasi yang diterimanya. Dilihat dari sebaran pilihan jawaban responden tidak ada yang memilih pilihan jawaban "Sangat Tidak Setuju" yaitu $0 \%$ dan responden yang memilih pilihan jawaban "Tidak Setuju" hanya sebanyak 4 orang $(7,8 \%)$ yang artinya hanya sebagian kecil responden saja yang merasa tidak mengerti akan informasi pencegahan penularan COVID-19 yang ditemui nya di instagram. Sisa nya dilihat dari sebaran pilihan jawaban responden 6 orang $(11,8 \%)$ memilih pilihan jawaban "Netral".
5. Pada indikator mengenai apakah instagram sangat efektif untuk memberikan edukasi tentang pencegahan penularan COVID-19, responden memberikan respon sangat baik, dengan mean 3,78. Dimana mayoritas responden memilih pilihan jawaban "Setuju" yaitu sebanyak 22 orang $(43,1 \%)$, serta responden yang memilih pilihan jawaban "Sangat Setuju" sebanyak 9 orang $(17,6 \%)$, dan tidak ada responden yang memilih pilihan jawaban "Tidak Setuju"dan "Sangat Tidak Setuju" yaitu $0 \%$. Artinya sebagian besar responden setuju bahwa aplikasi instagram sangat efektif untuk memberikan edukasi pencegahan penularan COVID-19 dan dengan memanfaatkan aplikasi instagram dapat mencapai tujuan pemerintah untuk mengurangi penularan COVID-19. Dilihat dari sebaran pilihan jawaban responden, sisa nya responden memilih pilihan jawaban "Netral" yaitu sebanyak 20 orang $(39,2 \%)$, sebagian kecil responden beranggapan instagram tidak begitu efektif dalam memberikan edukasi pencegahan penularan COVID-19.

6. Pada indikator mengenai apakah setelah melihat postingan instagram tentang pencegahan penularan COVID-19 responden akan berniat untuk melakukannya, dan responden pun memberikan respon yang sangat baik, dengan mean 3,96. Dimana sebagian besar dari responden memilih pilihan jawaban "Setuju" yaitu sebanyak 30 orang $(58,8 \%)$, dan responden yang memilih pilihan jawaban "Sangat Setuju" sebanyak 13 orang $(25,5 \%)$, yang artinya melalui pemanfaatan instagram ini untuk edukasi pencegahan penularan COVID-19 dapat membantu meningkatkan kesadaran seseorang untuk melakukan kegiatan penecegahan penularan COVID-19 sehinga menekan angka penuluran COVID-19. Dilihat dari sebaran pilihan jawaban responden pada pilihan jawaban "Netral" sebanyak 4 orang $(7,8 \%)$, pilihan jawaban 
"Tidak Setuju" sebanyak 1 orang, (2\%) dan pilihan jawaban "Sangat Tidak Setuju" sebanyak 3 orang $(5,9 \%)$, yang artinya hanya sebagian kecil saja responden yang tidak peduli akan penularan COVID-19.

7. Pada indikator mengenai kenyamanan dalam menggunakan aplikasi instagram untuk edukasi pencegahan penularan COVID-19, responden memberikan respon yang baik, dengan mean 3,69. Dilihat dari sebaran pilihan jawaban responden, sebanyak 11 orang (21,6\%) memilih pilihan jawaban "Sangat Setuju" dan sebanyak 18 orang $(35,3 \%)$ memilih pilihan jawaban "Setuju", yang artinya sebagian besar responden merasa nyaman menggunakan aplikasi instagram untuk edukasi pencegahan penularan COVID-19, baik dalam memberikan informasi edukasi pencegahan penularan COVID-19 maupun untuk mendapatkan edukasi pencegahan penularan COVID-19. Dan sebagian responden merasa kurang nyaman menggunakan aplikasi instagram untuk edukasi pencegahan penularan COVID-19 dilihat dari jumlah responden yang memilih pilihan jawaban "Netral" yaitu sebanyak 19 orang $(37,3 \%), 1$ orang (2\%) memilih pilihan jawaban "Tidak Setuju" dan 2 orang $(3,9 \%)$ memilih pilihan jawaban "Sangat Tidak Setuju".

\section{Kesimpulan}

Berdasarkan penelitian yang dilakukan dari hasil kuisioner "Pemanfaatan Aplikasi Instagram Dalam Edukasi Pencegahan Penularan COVID-19 Dikalangan Mahasiswa", dengan ini dapat ditarik kesimpulan bahwa dengan pemanfaatan aplikasi instagram untuk edukasi pencegahan penularan COVID-19 dikalangan mahasiswa dapat mencapai tujuannya secara efektif, sesuai dengan hasil kuisioner yang didapat sebagian besar responden memberikan respon postif dan setuju bawah aplikasi instagram efektif dalam mengedukasi mahasiswa mengenai pencegahan penularan COVID-19, dan dengan pemanfaatan aplikasi instagram dapat meningkatkan kesadaran mahasiswa akan melakukan tindakan pencegahan penularan COVID-19 yang akan membantu pemerintah untuk menekan tingkat penularan COVID-19, dengan itu diharapkan melalui mahasiswa dapat membantu menekan penyebaran COVID19 dan mempercepat pemulihan dunia ini dari COVID-19.

\section{Daftar Pustaka}

[1] O. Mungkasa, "Bekerja dari Rumah (Working From Home/WFH): Menuju Tatanan Baru Era Pandemi COVID 19," J. Perenc. Pembang. Indones. J. Dev. Plan., vol. 4, no. 2, pp. 126-150, 2020.

[2] K.-H. Chu, J.-P. Allem, T. B. Cruz, and J. B. Unger, "Vaping on Instagram: cloud chasing, hand checks and product placement," Tob. Control, vol. 26, no. 5, pp. 575-578, 2017.

[3] WHO, "Coronavirus," 2020. .

[4] N. F. Putri, E. Vionia, and T. Michael, "PENTINGNYA KESADARAN HUKUM DAN PERAN MASYARAKAT INDONESIA DALAM MENGHADAPI PENYEBARAN BERITA HOAX COVID-19," Media Keadilan J. Ilmu Huk., vol. 11, no. 1, pp. 98-111, 2020.

[5] E. Suprijanto and S. Arikunto, "Efektivitas pengelolaan kegiatan kelompok kerja guru (KKG) di Kecamatan Rembang, Purbalingga, Jawa Tengah," J. Penelit. Ilmu Pendidik., vol. 9, no. 2, pp. 141151, 2016.

[6] A. M. Idhom, "Update Corona 29 Mei 2020 di Indonesia \& Data Pandemi Dunia Terkini," Titro.id, 2020. . 
[7] Wikipedia, "Media Sosial," Wikipedia. .

[8] A. M. Kaplan and M. Haenlein, "Users of the world, unite! The challenges and opportunities of Social Media," Bus. Horiz., vol. 53, no. 1, pp. 59-68, 2010, doi: 10.1016/j.bushor.2009.09.003.

[9] Wikipedia, "Instagram," Wikipedia. p. 283, 1386.
[10] Pendidikanku.org, "Pengertian Edukasi Menurut Para Ahli," 2020. .

[11] Sugiyono, "Metodelogi Penelitian," 2002.

[12] R. Susilana, "Modul Populasi dan Sampel," Modul Prakt., pp. 3-4, 2015, [Online]. Available: http://file.upi.edu/Direktori/DUALMODES/PENELITIAN_PENDIDI KAN/BBM_6.pdf. 